\title{
Breeding objectives and economic values for traits of low input family- based beef cattle production system in the State of Rio Grande do Sul ${ }^{1}$
}

\section{Carlos Henrique Laske², Bruno Borges Machado Teixeira², Nelson José Laurino Dionello3,4, Fernando Flores Cardoso 4,5}

\footnotetext{
1 Research funded by CAPES, FAPERGS, MDA and International Foundation for Science.

2 Programa de Pós-Graduação em Zootecnia - UFPEL. Scholar from CAPES.

3 Faculdade de Zootecnia - UFPEL.

${ }^{4}$ Programa de Pós-Graduação em Zootecnia - UFPEL. Scholar from CNPq

5 Embrapa Pecuária Sul.
}

\begin{abstract}
The objectives of this study were to define breeding objectives and derive economic weights for production traits in family-based beef cattle systems, assess the sensitivity of these weights to changes in market and husbandry indicators and estimate the expected genetic changes in the selection criteria proposed. Based on data from the production systems, farms revenues and expenses, obtained from interviews and meetings with producers, a bioeconomic model was derived, relating biological traits of animals with the financial result of the production system based on calf-crop, selling male calves and culling cows for finishing. Traits considered in the model as breeding goals were weaning rate, weaning weight and cow weight. The economic weights, obtained by the partial derivative of the bioeconomic model with respect to the trait in question, assessed on the average value of the remaining traits, were $\mathrm{R} \$ 73.21 \%$ for weaning rate, $\mathrm{R} \$ 17.07 / \mathrm{kg}$ for weaning weight and $\mathrm{R} \$ 4.75 / \mathrm{kg}$ for cow weight. An index for joint selection of these three criteria would allocate $89.5 \%$ of importance to weaning rate, $6.9 \%$ for weaning weight and 3.6\% for cow weight. In this way, for every $\mathrm{R} \$ 100.00$ of genetic gain in this index, there would be an increase of $1.4 \%$ in weaning rate, but with reduction of $0.004 \mathrm{~kg}$ in weaning weight and $0.665 \mathrm{~kg}$ in cow weight due to negative genetic association between these traits. The proposed index and the relative importance identified for the economic traits can guide the selection decisions of smallholders, both in the choice of their animals and in the acquisition of bulls, cumulatively increasing the productivity of their herds.
\end{abstract}

Key Words: beef cattle, breeding objectives, economic weights, selection, smallholders

\section{Introduction}

Animal improvement aims to increase the frequency of favorable gene combinations in economically important traits for a given production system and, thereby, increase profitability, which is determined in part by the emphasis given on each trait included in the breeding objectives (Smith, 1983).

The definition of breeding objectives must be the first step in the outset of a genetic improvement program (Urioste et al., 1998; Smith, 1985; Ponzoni, 1986; Fewson, 1993), and traits considered in the breeding objective are the basis for the formulation of a profit function from which economic values are derived (Vercesi Filho, 1998). The economic importance of biological traits to be included in a breeding objective is assessed by their economic weights, defined as the expected increase in herd annual profit resulting from a unit increase in a trait due to selection (Jorge Júnior et al., 2007).

In the case of low-input beef cattle smallholders, which represent about 40,000 families in the southern half of Rio Grande do Sul, the identification of objectives should be based on the production systems adopted and market shared by this segment of the producers, given that familybased operations have their own features and do not necessarily follow the technological model of modern beef cattle industry (Ribeiro, 2003).

In addition, the genetic improvement of low input cattle from smallholders must be treated differently from traditional elite seedstock breeding programs, considering, besides environmental production system and market aspects, their cultural way of life and production (Laske et al., 2009). Easily obtained traits with few measurements during the life of the animals should be emphasized. Fertility, weaning weight and adaptation have been recognized as the most important traits for these systems (Laske et al., 2009).

The objectives of this study were to define breeding objectives and to derive economic weights for production traits of low input beef cattle smallholders, determine their sensitivity to changes in production and market indicators and estimate the expected genetic changes in the selection criteria proposed. 


\section{Material and Methods}

The determination of the set of biological traits economically important for low-input beef cattle production system was carried out through the formulation of a bioeconomic model, using the following steps (Ponzoni \& Newman, 1989; Cardellino, 1995): 1) specifying the production system and the market, 2) making an inventory of the business revenues and expenses, 3) determining the biological traits that affect these revenues and expenses and 4) deriving relative economic weights for the traits identified in item three.

The characterization of the production system was obtained from interviews with farmers using a semistructured questionnaire, participatory meetings and animal production measurements within a genetic improvement project which comprised 30 farms in three municipalities located in the southern half of the State of Rio Grande do Sul, Brazil. Production systems are all cow-calf operations based on native pasture and under extensive conditions with an average herd size of 57 heads and low production indices (Table 1).

The stocking rate in kg of live weight per hectare was calculated considering the total area of the farm that was used exclusively with livestock production, including areas of native woods, wetlands and ponds. In general, all females are jointly managed and heifers are mated as they come into heat without a pre-determined age, but this usually happens when they are around 36 months old. Most producers do not have a defined breeding season period and the bulls remain with the cows and heifers for long periods or throughout the whole year. Calves are weaned between eight and ten months of age, when all males are generally marketed. In the studied systems, the proportion between the replacement rate (20\%) and weaning rate (47\%) does not

Table 1 - Animal production and herd performance indicators of low input beef cattle smallholders considered in economic weight calculations

\begin{tabular}{lcc}
\hline Traits & Unit & Value \\
\hline Number of cows per herd & Heads & 28 \\
Weaning rate & $\%$ & 47 \\
Age at first calving & Months & 48 \\
Average male calves live weight at marketing & $\mathrm{kg}$ & 131.6 \\
Average female calves live weight at marketing & $\mathrm{kg}$ & 125.0 \\
Average mature cow weight & $\mathrm{kg}$ & 329.0 \\
Death rate/year & $\%$ & 2.0 \\
Age of calves at marketing & Months & 8 \\
Age of heifers at marketing & Months & 8 \\
Cows replacement rate & $\%$ & 20.0 \\
Stocking rate & $\mathrm{kg} / \mathrm{ha}$ & 382.5 \\
\hline
\end{tabular}

${ }^{1}$ Mean value for all categories of the herd after weaning. generate surplus heifers, because the number females generated is equivalent to that required for replacement of culled cows (Figure 1 ).

To develop the equations of the bioeconomic model, the production system revenues and expenses were identified, since the profit is a function of income and costs generated by each animal category composing the herd (Ponzoni \& Newman, 1989; Bittencourt et al., 2006).

The revenue sources of low input beef cattle smallholders are basically derived from the sale of male calves after weaning and cull cows for finishing. The traits that affect the revenue with respect to the marketed calves are number of cows, weaning rate and weaning weight. Surplus female calves will only be available for sale if the weaning rate is higher than necessary to supply the replacement and mortality rates of cows and heifers during the rearing. In the case of cull cows, the value obtained on the sale depends on the cow mature weight, the number of cows and replacement rate.

The variable expenses, which is proportional to the herd size and productivity level, considering an extensive production system on native pasture, a herd without specific breed definition, using natural mating between from October to April and weaning usually in April or May, was attributed to animal feeding, health treatments (vaccinations, worming, acaricide, etc.) and mineral supplementation.

The annual cost of management practices by category (Table 2) was calculated based on the kinds and frequencies of health treatments reported by producers in the survey, by multiplying the drug dose price and other inputs used on a per $\mathrm{kg}$ basis by the average live weight of each cattle category and by the number of treatments per year. Moreover, these costs included the cost of mineral

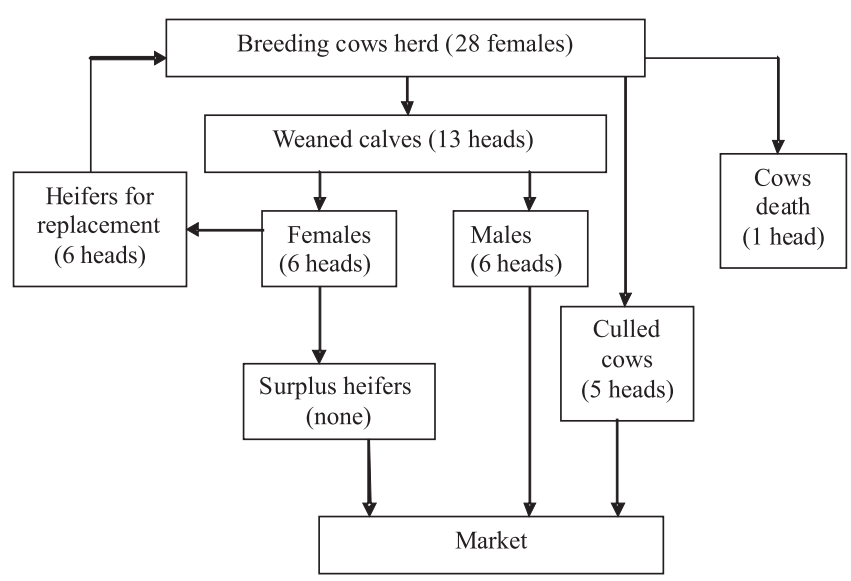

Figure 1 - Composition and workflow of the herd used in the specification of the production system and marketing of low input beef cattle smallholders. 
Table 2 - Annual costs of the management practices by animal category in low input beef cattle smallholders

\begin{tabular}{|c|c|c|c|c|c|}
\hline \multirow[t]{2}{*}{ Treatment } & \multicolumn{5}{|c|}{ Category } \\
\hline & Male calves & Female calves & Yearling heifers & Two-year old heifers & Adult cow \\
\hline Acaricides & $\mathrm{R} \$ 0.32$ & $\mathrm{R} \$ 0.32$ & $\mathrm{R} \$ 0.96$ & $\mathrm{R} \$ 0.96$ & $\mathrm{R} \$ 0.96$ \\
\hline Worming & $\mathrm{R} \$ 1.81$ & $\mathrm{R} \$ 1.81$ & $\mathrm{R} \$ 2.86$ & $\mathrm{R} \$ 3.90$ & $\mathrm{R} \$ 4.62$ \\
\hline $\begin{array}{l}\text { Vaccines (foot and mouth disease, } \\
\text { clostridia, brucellosis }{ }^{1} \text { ) }\end{array}$ & $\mathrm{R} \$ 2.64$ & $\mathrm{R} \$ 5.14$ & $\mathrm{R} \$ 2.64$ & $\mathrm{R} \$ 2.64$ & $\mathrm{R} \$ 2.64$ \\
\hline Supplementation (plain and mineral salt) & $\mathrm{R} \$ 3.05$ & $\mathrm{R} \$ 3.05$ & $\mathrm{R} \$ 3.20$ & $\mathrm{R} \$ 4.05$ & $\mathrm{R} \$ 5.17$ \\
\hline Total annual & $\mathrm{R} \$ 10.00$ & $\mathrm{R} \$ 12.50$ & $\mathrm{R} \$ 13.04$ & $\mathrm{R} \$ 16.01$ & R\$ 18.98 \\
\hline
\end{tabular}

${ }^{1}$ Only female calves.

supplementation, and they were determined by dividing the total amount of supplement provided per year by the number of heads, considering the category average weight and, in the case of calves, the number of days per year that they remain on the farm.

Since animals are raised exclusively in extensive pasture conditions, preventing objective measures of consumption, the cost of animal feeding was estimated based on the exploited stocking rate in $\mathrm{kg} / \mathrm{ha}$, individual body weight and the opportunity cost of a hectare of land, based on its lease value (Table 3). In the evaluated region, livestock suitable land, similarly to that of the farms included in this study have lease values indexed by the price of live cattle, around $29 \mathrm{~kg} / \mathrm{ha} / \mathrm{year}$. Thus, the cost per kg of dry matter consumed by a cow was estimated by the lease cost of a hectare per year $(29 \mathrm{~kg} \times$ price of live cattle $\mathrm{kg}$ ) divided by stocking rate in $\mathrm{kg}$ per hectare (382.5 kg/ha), by the number of days per year that each category remains in pasture and by the expected consumption of $2.5 \%$ of forage dry matter in relation to the animal weight (NRC, 2000).

Other costs, such as fixed expenditures, depreciation and manpower are not affected by increasing the animal performance by selection (Jorge Júnior et al., 2007) and, therefore, vanish when the partial derivative with respect to the traits considered is calculated to determine their economic values (Ponzoni \& Newman, 1989; Newman et al., 1992). Thus, fixed costs were represented symbolically in the bio-economic model, without the need to be determined objectively.

Considering regional market prices (Table 3), the total system profit $(P)$ was obtained in the bio-economic model by the following equations:

$P_{T}=P(m c)+P(f c)+P\left(h e_{1}\right)+P\left(h e_{2}\right)+P(c o)$ - fixed costs, where

$P(m c)=C N \times 0.5 \times W R \times((W W \times 2.5)-(0.025 \times W W \times 0.71 \times 0.0206 \times$

$\times 180)-10.0)$,
Table 3 - Sale prices ${ }^{1}$ of animal based on live weight (LW) and annual costs of each animal category that influence the profit of the production system

\begin{tabular}{lcc}
\hline Trait & Unit & Value \\
\hline Sale price of male calves & $\mathrm{R} \$ / \mathrm{kg}$ of $\mathrm{LW}$ & 2.50 \\
Sale price of female calves & $\mathrm{R} \$ / \mathrm{kg}$ of $\mathrm{LW}$ & 2.30 \\
Sale price of cull cows & $\mathrm{R} \$ / \mathrm{kg}$ of $\mathrm{LW}$ & 2.00 \\
Cost of land lease & $\mathrm{R} \$ / \mathrm{ha} / \mathrm{year}$ & 71.84 \\
Cost of $\mathrm{kg}$ of herbage dry matter & $\mathrm{R} \$ / \mathrm{kg}$ & 0.0206 \\
\hline
\end{tabular}

${ }^{1}$ Source of livestock sales price: EMATER/RS.

$P(f c)=C N \times 0.5 \times W R \times$

$\left(\left(W W \times 2.30 \times\left(1-\frac{R R \times(1+3 \times M R)}{0.5 \times W R}\right)\right)-(0.025 \times W W \times 0.71 \times 0.0206 \times\right.$

$\times 180)-12.5)$

$P\left(h e_{1}\right)=C N \times R R \times(1+2 \times M R) \times(0-(0.025 \times C W \times 0.47 \times 0.0206 \times$

$\times 365)-13.0)$,

$P\left(h e_{2}\right)=C N \times R R \times(1+M R) \times(0-(0.025 \times C W \times 0.63 \times 0.0206 \times$

$\times 365)-16.0)$,

and

$P(c o)=C N \times((R R \times C W \times 2.00)-(0.025 \times C W \times 0.0206 \times 365)-19.0)$.

here $P$ is the gross profit obtained from each category: $m c=$ male calf; $m f=$ female calf; $h e_{1}$ and $h e_{2}=$ one- and two- year- old heifers, respectively; co = cow, and $P_{T}$ is the sum of the five category equations minus the fixed costs. We also have that $C N$ is the number of cows, $R R$ is the replacement rate, $M R$ the mortality rate and $C W$ is the weight of the cow.

In the equations above, considering the current weaning rate in the low input systems studied, only male calves and cull cows are sold, contributing to revenues. However, the equation for female calves $P\left(f_{c}\right)$ includes the term $1-\frac{R R \times(1+3 \times M R)}{0.5 \times W R}$, which represents a possible 
surplus of heifers for sale that will be available if the weaning rate is increased. Only those heifers required for breeding herd replacement are kept, considering the expected mortality rate after weaning. However, they should be included in the calculations above because of the costs they add to the system.

The economic values were obtained from the partial derivative of the bio-economic model with respect to each trait in the breeding objective (Moav \& Hill, 1996; Harris, 1970 apud Queiroz et al., 2005), evaluated at the average value of all other variables in the model. The terms that do not involve the traits considered in the selection objective disappear when the partial derivative is obtained from the bio-economic model with respect to each trait (Ponzoni \& Newman, 1989; Bittencourt et al., 2006) and this ensures that there is no need to consider in this model costs that do not depend on the performance of animals, such as fixed costs.

Since the economic values are influenced by changes in market prices of both animals and inputs, the effects of various scenarios of herd performance and prices on economic values were assessed, considering an increase or decrease of $20 \%$ in relation to the observed values for the considered variables, similarly to the proposition by Bittencourt et al. (2006).

For selection in the population, one assumes the usage of a linear mixed model to obtain best linear unbiased predictions (BLUP) of genetic values for the selection criteria (Henderson, 1984) measured in candidate animals and that these values are combined into a genetic selection index according to their economic values. To express the relative economic importance of each trait in the herd improvement, economic values were multiplied by the genetic standard deviation of the trait to represent the geneticeconomic variation available for selection in every trait and, hence, its relative importance in the selection index (Ponzoni \& Gifford, 1990).

Due to the lack of genetic parameters estimated for this population and the scarcity of estimates involving fertility, especially for weaning rate in the literature (e.g., Koots et al., 1994a,b; Lôbo et al., 2000), the genetic and phenotypic (co)variance values used in this study were composed based on estimates from the Nellore herd from the Instituto de Zootecnia de Sertãozinho, São Paulo (Mercadante et al., 2000; Mercadante, personal communication $)^{1}$ and from Australia (Burrow, 2001).

Since the heritability used for weaning rate, a binary measure, was estimated by Mercadante (personal communication $)^{1}$ in the underlying scale, the values of the variance components were transformed into the observed scale in accordance with the following equation (Gianola, 1982):

$\mathrm{h}_{b}^{2}=\mathrm{z}^{2} \mathrm{~h}_{h}^{2} /(\mathrm{p}(1-\mathrm{p}))$,

where $h^{2}{ }_{n}$ is the heritability in the normal or underlying scale, $h^{2}{ }_{b}$ is the heritability in the observed or binomial scale, $p=0.47$ is the population rate or average, $x$ is the ordinate of the normal curve corresponding to $p$, and $z$ is the height of the curve at $x$, i.e.:

$\mathrm{z}=\frac{1}{\sqrt{2 \pi}} \mathrm{e}^{-x^{2} / 2}$

Finally, the adopted genetic $G$ and phenotypic P (co)variance matrices for the selection index criteria were:

$\mathbf{G}=\operatorname{var} g\left[\begin{array}{c}W W \\ C W \\ W R\end{array}\right]=\left[\begin{array}{ccc}139.2000 & 158.3810 & 0.0847 \\ 158.3810 & 500.5700 & -2.6413 \\ 0.0847 & -2.6413 & 0.129\end{array}\right]$,

and

$\mathbf{P}=\operatorname{var} p\left[\begin{array}{c}W W \\ C W \\ W R\end{array}\right]=\left[\begin{array}{ccc}484.0800 & 265.2663 & 0.0000 \\ 265.2663 & 1334.8100 & 1.0866 \\ 0.0000 & 1.0866 & 1.129\end{array}\right]$

In addition, the methodology described by Schneeberger et al. (1992) was used to predict the genetic gain in each trait for each unit of monetary genetic progress in the selection index (in Brazilian Reals), as well as their relative contribution to this one Real of gain in income for the production system due to selection. To this end, the following approximation of the selection index variance was used:

$\mathrm{s}_{I}^{2}=\mathbf{b}^{\prime} \operatorname{Vãr}\left(\hat{\mathrm{u}}_{\mathrm{i}}\right) \mathbf{b}$,

where $\mathbf{b}$ is the vector of economic values and

Vãr $\left(\hat{\mathrm{u}}_{\mathrm{i}}\right)=\mathbf{B}^{\prime} \times \mathbf{P} \times \mathbf{B}$

is an approximation of the breeding values covariances, in which

$\mathbf{B}=\mathbf{P}^{-1} \times \mathbf{G}$.

Thus, the genetic gain in selection criteria resulting from a one-Real increase in the index were given by,

$\mathbf{d}=\left(1 / \mathrm{s}_{I}^{2}\right) \operatorname{Vãr}\left(\hat{\mathrm{u}}_{\mathrm{i}}\right) \mathbf{b}$.

Finally, the contribution in cents of Real of each selection criteria for a one-Real increase of the index was obtained by multiplying each element of $d$ (genetic gain) with the corresponding element in $\mathrm{b}$ (economic value), i.e., by $\mathrm{d} \# \mathrm{~b}$, with \# denoting the Hadamard product (element-byelement).

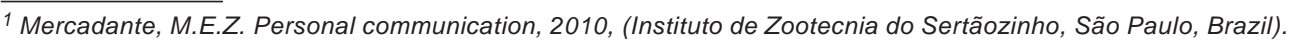




\section{Results and Discussion}

The economic values $\left(b_{i}\right)$ of the traits included in the selection objective (Table 4) estimate the system profit change resulting from a unitary increase in each of these traits while keeping all others constant, being expressed in $\mathrm{R} \$$ per trait unit. The largest gains for these low input beef cattle systems can be obtained by selection for weaning rate, followed by weaning weight and finally, by the cow weight. The relative importance in genetic-economic units $\left(b_{i} \times \sigma_{g(i)}\right)$, where $\sigma_{g(i)}$ is the genetic standard deviation, provides an objective indication of the potential of economic change in each trait considered for the selection in comparison with the other criteria (Koots \& Gibson 1998) and was also much higher for weaning rate (Table 4).

The greater relative economic importance that the reproductive trait (weaning rate) showed in comparison with other traits in the low input systems studied can be attributed, at least in part, to the very low reproductive levels of these herds, since the economic importance of a trait is bigger when its actual performance is relatively lower (Albera et al., 2002 apud Krupa et al., 2005).

In terms of opportunity for genetic-economic change in the traits, combining their economic values with the genetic variability for selection in each of them (Table 4), larger gains can be achieved by an emphasis on reproduction, i.e., increasing the number of calves produced, and only $10.5 \%$ of the relative importance is placed on increasing the weight per unit of output, summing calves and their dams traits. Phocas et al. (1998), although working with a full livestock cycle system, where finishing and carcass traits are also considered, found a $59 \%$ relative importance for reproductive traits in a selection index weighted by economic values in a Limousine herd.

The presence of genetic-economic variation does not necessarily mean that the trait can be used, since the availability of phenotypic measurements in candidate animals for selection and prediction of their genetic values may be more difficult for a certain trait than another (Bittencourt et al., 2006). In practice, the observed contribution of each trait for the genetic-economic gain will depend not only on the availability of genetic-economic variation, but also on the accuracy with which the genetic value of the trait in question can be predicted (Ponzoni, 1992). Thus, as the heifer calves will be selected by weaning rate before being phenotypically evaluated, the weaning rate progress and its impact on the outcome of the productive system could be lower than expected, due to its lower heritability and because it is a sex limited trait measured later in the cow reproductive life.

The results observed for economic values based on the studied scenario (Table 4) are subject to variations due to fluctuations in the market, cost of inputs and production indices. The sensitivity of economic values in light of variations of some indicators of the production system was assessed projecting scenarios of $20 \%$ increase or reduction in selling prices per kg of live weight, weaning rate and land lease prices (Table 5).

In the case of a reduction in the cattle sale price, weaning rate increased its relative importance to $90.6 \%$, with weaning weight remaining constant and cow weight reducing its relative importance to $2.5 \%$ (Table 5). This indicates that the more adverse the market conditions, the greater the contribution of the increase in reproductive traits (weaning rate) to the income of the productive system.

Variations in weaning rate affected the relative importance of weaning weight and weaning rate (Table 5). The lower the herd productive level for weaning rate, the greater the relative importance of this trait. On the other hand, as the herd has a higher number of calves weaned per cow mated, the economic value of calves weaning weight increases. The economic value of weaning weight in the low input systems studied was R $\$ 0.60$ per cow/year. Jorge Júnior et al. (2007), working with Nellore animals in two different systems - cow-calf or full cycle operations - obtained, respectively, the values of $\mathrm{R} \$ 0.40$ and $\mathrm{R} \$ 0.34$ per cow/year. The difference between these values and that of the low input smallholders systems is due, at least in part, to much lower weaning rates in the latter and the fact that as the weaning rate increases its relative economic value compared with the weaning weight decreases.

Bittencourt et al. (2006), working with Zebu cattle in two production systems, one comprised solely of cow-calf operation and another that performed the complete livestock cycle, identified the weaning rate as the trait with the highest economic values sensitivity to changes in

Table 4 - Economic values and relative importance of production traits of the breeding objective of low input beef cattle smallholders

\begin{tabular}{lccc}
\hline Trait & Economic value $\left(b_{i}\right)$ & $b_{i} \times$ genetic standard deviation & Relative importance \\
\hline Weaning weight, $\mathrm{kg}$ & $\mathrm{R} \$ 17.07 / \mathrm{kg}$ & $\mathrm{R} \$ 201.35$ & $6.9 \%$ \\
Weaning rate, $\%$ & $\mathrm{R} \$ 73.21 \%$ & $\mathrm{R} \$ 2630.50$ & $89.5 \%$ \\
Mature cow weight, $\mathrm{kg}$ & $\mathrm{R} \$ 4.75 / \mathrm{kg}$ & $\mathrm{R} \$ 106.30$ & $3.6 \%$ \\
\hline
\end{tabular}


production circumstances assessed. This trait affects all sources of revenue and costs: the more calves produced, the higher the income (Bittencourt et al., 2006). The importance of weaning rate was also observed by Newman et al. (1992) in New Zealand, who found that the economic value of the number of weaned calves is 200 times greater than the carcass weight.

When varying the land lease cost, the weaning weight and weaning rate suffered practically no change in their economic values (Table 5). However, the cow weight value was substantially altered due to the changes in herd maintenance costs, since the cost of kg of dry matter consumed is directly proportional to the lease cost in the proposed model. In this sense, bigger cows were favored when feed costs were lower. On the other hand, the economic value of the cow mature size decreases with increasing feed costs (Kiuyts et al., 2003), since the benefit of selling heavier cows is limited by higher costs for herd maintenance.

The joint selection for the three traits considered in the selection objective to maximize the production system economics, assuming that these same traits are the criteria measured in the genetic evaluation of the target population, should be performed by a selection index, measured in
Reals, which weighs the breeding value (BV) of the animal in each trait by the economic value of that trait (Hazel, 1943; Henderson, 1963), as presented below:

$\mathrm{I}_{(\mathrm{R} \$) i}=73.21 \times \mathrm{BV}_{(\mathrm{WR}) i}+17.07 \times \mathrm{BV}_{(\mathrm{WW}) i}+4.75 \times \mathrm{BV}_{(\mathrm{CW}) i}$, where $\mathrm{I}_{(\mathrm{R} \$) i}=$ index or aggregated value in monetary units of Real calculated for animal $i$, and $\mathrm{BV}_{(\mathrm{WR}) i}, \mathrm{BV}_{(\mathrm{WW}) i}$ and $\mathrm{BV}_{(\mathrm{CW}) i}$ are, respectively, the breeding values of animal $i$ for weaning rate, weaning weight and mature cow weight.

It can be observed that, in terms of genetic changes and expected trait contributions, for every R $\$ 100.00$ of genetic progress through selection based on the proposed index (Table 6), all the positive economic result comes from an improvement of $1.4 \%$ in herd weaning rate, which translates to an increase of R \$ 103.22 in system profit. However, when selecting the herd through the economic index proposed, assigning the majority of relative importance to weaning rate, a genetic progress of $\mathrm{R} \$ 100.00$ in the index will result in reducing the average cow weight $(-0.665 \mathrm{~kg})$ and, consequently, a negative contribution to system profit of this trait ( $\mathrm{R}$-3.15). Weaning weight remained practically constant, showing very little variation $(-0.003 \mathrm{~kg})$ for each $\mathrm{R} \$ 100.00$ increase in the herd average performance with respect to the selection index, which would have a negligible impact on the profitability (Table 6).

Table 5 - Economic values and relative importance (in parentheses) for productive traits and their sensitivity to changes in economic and animal performance indicators

\begin{tabular}{|c|c|c|c|c|}
\hline \multirow{3}{*}{$\begin{array}{l}\text { Trait } \\
\text { Weaning weight, kg }\end{array}$} & \multicolumn{4}{|c|}{ Changed indicator } \\
\hline & \multicolumn{4}{|c|}{ Base situation } \\
\hline & \multicolumn{2}{|c|}{$\mathrm{R} \$ 17.07 / \mathrm{kg}$} & \multicolumn{2}{|c|}{$(6.9 \%)$} \\
\hline \multirow[t]{2}{*}{ Mature cow weight, kg } & \multicolumn{2}{|c|}{$\mathrm{R} \$ 4.75 / \mathrm{kg}$} & \multicolumn{2}{|c|}{$(3.6 \%)$} \\
\hline & \multicolumn{4}{|c|}{ Price per kg of live weight } \\
\hline \multirow[t]{3}{*}{ Mature cow weight, kg } & $\mathrm{R} \$ 2.51 / \mathrm{kg}$ & $(2.5 \%)$ & R\$ 6.99/kg & $(4.4 \%)$ \\
\hline & \multicolumn{4}{|c|}{ Weaning rate } \\
\hline & \multicolumn{2}{|c|}{$20 \%$ reduction } & \multicolumn{2}{|c|}{$20 \%$ increase } \\
\hline Weaning weight, kg & R\$ $10.92 / \mathrm{kg}$ & $(4.5 \%)$ & R\$ 23.21/kg & $(9.1 \%)$ \\
\hline Weaning rate, \% & $\mathrm{R} \$ 73.21 \%$ & $(91.8 \%)$ & R\$ 73.21\% & $(87.4 \%)$ \\
\hline Mature cow weight, kg & \multicolumn{4}{|c|}{ Land lease cost/ha/year } \\
\hline Weaning rate, \% & R\$ $73.64 \%$ & $(88.7 \%)$ & $\mathrm{R} \$ 72.78 \%$ & $(90.4 \%)$ \\
\hline Mature cow weight, kg & $\mathrm{R} \$ 6.04 / \mathrm{kg}$ & $(4.5 \%)$ & $\mathrm{R} \$ 3.46 / \mathrm{kg}$ & $(2.7 \%)$ \\
\hline
\end{tabular}

Table 6 - Trait changes and contributions for each $\mathrm{R} \$ 100.00$ increase in the index

\begin{tabular}{lcc}
\hline Trait & Trait change per $\mathrm{R} \$ 100.00$ increase in the index & Trait contribution for each $\mathrm{R} \$ 100.00$ increase in the index \\
\hline Weaning weight, $\mathrm{kg}$ & $-0.004 \mathrm{~kg}$ & $\mathrm{R} \$-0.06$ \\
Weaning rate, $\%$ & $1.41 \%$ & $\mathrm{R} \$ 103.22$ \\
Mature cow weight, $\mathrm{kg}$ & $-0.665 \mathrm{~kg}$ & $\mathrm{R} \$-3.16$
\end{tabular}


Although the cow weight and weaning weight have positive economic values in the selection index proposed, they had negative genetic gain due to a negative genetic correlation, especially between cow weight and weaning rate, a complex trait that includes fertility, maternal ability and survival. In the long run, reducing the size of the cows may have consequences for market acceptance of these smaller cows, given that the regional market demand for heavy carcasses to meet export customers. Perotto et al. (1999) pointed out that the commercial value of a beef carcass in Brazil is determined by a set of characteristics, with primary emphasis on weight.

Finally, it should be noted that the proposed criteria, weaning rate, weaning weight and cow weight, besides being precisely the selection objective traits, can be feasibly obtained at the low input beef cattle smallholders at weaning time. The performance of animals can be monitored by weighing calves and cows at weaning using a portable scale system, as developed by Cardoso et al. (2006), which facilitates the collective acquisition and use. On the other hand, if the producers are unable or lack interest to control performance of their animals, they still can use economic values to guide their choices of bulls, electing those that transmit higher fertility to their daughters, increasing the number of calves weaned, but preferably also having higher weaning weights.

\section{Conclusions}

Despite the low heritability for reproductive traits, the weaning rate is the trait that has the greatest impact on profit and should be taken into account in the implementation of breeding programs for low input familybased beef cattle operations. The relative importance of weaning rate was consistently higher than the weaning and cow weights, and not very sensitive to variations of market and production system indicators. The proposed index and the relative economic importance of the identified traits can guide selection decisions of low input beef cattle smallholders, both in choosing their replacement animals and in the acquisition of breeding stock, to cumulatively increase the productivity levels of their herds.

\section{References}

BITTENCOURT, T.C.C.; LÔBO, R.B.; BEZERRA, L.A.F. Objetivos de seleção para sistemas de produção de gado de corte em pasto: ponderadores econômicos. Arquivo Brasileiro de Medicina Veterinária e Zootecnia, v.58, n.2, p.196-204, 2006.

BURROW, H.M. Variances and covariances between productive and adaptive traits and temperament in a composite breed of tropical beef cattle. Livestock Production Science, v.70, p.213-233, 2001.

CARDELLINO, R.A. Mejora genetica de bovinos de carne en condiciones extensivas. Archivos de Zootecnia, v.44, p.123-136, 1995.

CARDOSO, F.F.; PALMA, T.S.; OLIVEIRA, M.M. Sistema portátil de pesagem para bovinos. Bagé: Embrapa Pecuária Sul, 2006. 20p. (Documentos 59).

FEWSON, D. Definition of the breeding objectives. In: BARWICK, S.A.; FEWSON, D.; GRASER, H.U. et al. (Eds.) Design of livestock breeding programs. Armidale: University of New England, 1993. p.53-58.

GIANOLA, D. Theory and analysis of threshold characters. Journal of Animal Science, v.54, p.1079-1096, 1982.

HAZEL, L.N. The genetic basis for constructing selection indexes. Genetics, v.28, n.6, p.476-490, 1943.

HENDERSON, C.R. Application of linear models in animal breeding. Guelph, Ontario: University of Guelph, 1984. 462p.

HENDERSON, C.R. Selection index and expected genetic advance. In: HANSON, W.D.; ROBINSON, A.F. (Eds.). Statistical genetics and plant breeding. Washington: NAS-NRC, 1963. p.141-163.

JORGE JÚNIOR, J.; CARDOSO, V.L.; ALBUQUERQUE, L.G. Objetivos de seleção e valores econômicos em sistemas de produção de gado de corte no Brasil. Revista Brasileira de Zootecnia, v.36, n.5, p.1549-1558, 2007.

KIUYTS, J.F.; NESER, F.W.C.; BRADFIELD, M.J. Development of breeding objectives for beef cattle breeding: Derivation of economic values. South African Journal of Animal Science, v.33, p.142-158, 2003.

KOOTS, K.R.; GIBSON, J.P. Economic values for beef production traits from a herd level bioeconomic model. Journal of Animal Science, v.78, p.29-45, 1998.

KOOTS, K.R.; GIBSON, J.P.; SMITH, C.; WILTON, J.W. Analyses of published genetic parameter estimates for beef production traits. 1. Heritability. Animal Breeding Abstracts, v.62, p.309-338, 1994a.

KOOTS, K.R.; GIBSON, J.P.; WILTON, J.W. Analyses of published genetic parameter estimates for beef production traits. 2 . Phenotypic and genetic correlations. Animal Breeding Abstracts, v.62, p.825-852, 1994b.

KRUPA, E.; WOLFOVÁ, M.; PEŠKOVIÈOVÁ, D. et al. Economic values of traits for Slovakian Pied cattle under different marketing strategies. Czech Journal Animal Science, v.50, p.483-492, 2005.

LASKE, C.H.; CARDOSO, F.F.; TEIXEIRA, B.B.M. et al. Estratégias para o melhoramento genético participativo de bovinos de corte na pecuária familiar do Rio Grande do Sul. In: REUNIÃO ANUAL DA SOCIEDADE BRASILEIRA DE ZOOTECNIA, 46., 2009, Maringá. Anais... Maringá: Sociedade Brasileira de Zootecnia, 2009. (CD-ROM).

LÔBO, R.N.B.; MADALENA, F.E.; VIEIRA, A.R. Average estimates of genetic parameters for beef and dairy cattle in tropical regions. Animal Breeding Abstracts, v.68, n.6, p.433-462, 2000.

MERCADANTE, M.E.Z.; LÔBO, R.B.; OLIVEIRA, H.N. Estimativas de (co)variâncias entre características de reprodução e de crescimento em fêmeas de um rebanho Nelore. Revista Brasileira de zootecnia, v.29, n.4, p.997-1004, 2000.

NATIONAL RESEARCH COUNCIL - NRC. Nutrients requeriments of beef cattle. 7.ed. Washington, D.C., 2000. 244p.

NEWMAN, S.; MORRIS, C.A.; BAKER, R.L. et al. Genetic improvement of beef in New Zealand: breeding objectives. Livestock Production Science, v.32, p.111-130, 1992.

PEROTTO, D.; MOLETTA, J.L.; CUBAS, A.C. Características da carcaça de bovinos Canchim e Aberdeen Angus e de seus cruzamentos recíprocos terminados em confinamento. Ciência Rural, v.29, n.2, p.331-338, 1999.

PONZONI, R.W. A profit equation for the definition of the breeding objective of Australian Merino sheep. Journal Animal Breeding Genetics, v.103, p.342-357, 1986. 
PONZONI, R.W.; GIFFORD, D.R. Developing breeding objectives for Australian Cashmere goats. Journal of Animal Breeding Genetics, v.107, p.351-370, 1990 .

PONZONI, R.W.; Newman, S. Developing breeding objective for Australian beef cattle production. Animal Production, v.49, p.35-47, 1989.

PONZONI, R.W. Genetic improvement of hair sheep in the tropics. Rome: FAO, 1992. 162p. (FAO Animal Production and Health, Paper 101).

PHOCAS, F.; BLOCH, C.; CHAPELLE, P. et al. Developing a breeding objective for a French purebred beef cattle selection programme. Livestock Production Science, v.57, p.49-65, 1998.

QUEIROZ, S.A.; PELICIONI, L.C.; SILVA, B.F. et al. A. Índices de seleção para um rebanho Caracu de duplo propósito. Revista Brasileira de Zootecnia, v.34, n.3, p.827-837, 2005.

RIBEIRO, C.M. pecuária familiar na região da campanha do Rio Grande do Sul. in: pecuária familiar. Emater. Rio Grande do Sul/
ASCAR, Porto Alegre (Série Realidade Rural), v.34, p.11-45, 2003.

SCHNEEBERGER, M.; BARWICK, S.A.; CROW, G.H. et al. Economic indices using breeding values predicted by BLUP. Journal of Animal Breeding Genetics, v.109, p.180-187, 1992.

SMITH, C. Effects of changes in economic weight on the efficiency of index selection. Journal of Animal Science, v.56, p.1057-1064, 1983.

SMITH, C. Scope for selecting many breeding stocks of possible economic value in the future. Animal Production, v.41, p.403-412, 1985.

URIOSTE, J.I.; PONZONI, R.W.; AGUIRREZABALA, M. et al. Breeding objectives for pasture-fed Uruguayan beef cattle. Journal of Animal Breeding and Genetics, v.115, n.1-6, p.357-373, 1998.

VERCESI FILHO, A.E. Objetivos econômicos da seleção de gado de leite. In: SIMPÓSIO NACIONAL DE MELHORAMENTO ANIMAL, 1998, Uberaba. Anais...Viçosa, MG: UFV, 1998. p.135-145. 